\title{
LEADERSHIP SEBAGAI PRIMARY FORCES DALAM MENINGKATKAN DAYA SAING PERGURUAN TINGGI
}

\author{
Engkos Achmad Kuncoro \\ Jurusan Manajemen, Fakultas Ekonomi dan Bisnis, Bina Nusantara University \\ Jln.K.H. Syahdan No.9 Palmerah, Jakarta Barat 11480 \\ eak@binus.edu
}

\begin{abstract}
Universities as an organization are always influenced by the dynamic external environment, in both national and global levels. Therefore, in order to maintain its competitiveness for its sustainability, the role of university as the center of knowledge and science, as well as the center of research and of Community Service shall continue to be competitive and ensure their sustainability growth. The purpose of this paper is an in depth study of factors influencing the competitiveness of universities in Indonesia. The method used in this work is using the review of the literature (studies Reader). Literature Review is intended to solve a problem which is basically based on the critical and comprehensive review of the relevant collection materials. Based on the study found that the aspects of leadership while Higher Education as a driving force to attempt the power of competitiveness strengths in order to escalate in the competition areas, and obtain results of competition result as expected by both terms based on students quality and quantity, adequate earning income, social and cultural attributes to the organizational image building.
\end{abstract}

Keywords: leadership, competitive strengths, competition areas, competition result

\begin{abstract}
ABSTRAK
Perguruan tinggi sebagai sebuah organisasi dalam perkembangannya tidak bisa lepas dari dinamika perubahan eksternal yang sangat dinamis baik di tingkat nasional maupun global. Untuk menghadapi tantangan itu, maka peran perguruan tinggi sebagi pusat ilmu pengetahuan, pusat penelitian dan pusat pengabdian masyarakat harus dikelola sebagai sebuah entitas korporat agar tetap mempunyai daya saing dalam menjamin kelangsungan hidupnya. Tujuan tulisan ini adalah untuk melakukan kajian secara mendalam atas faktor-faktor apa saja yang berpengaruh terhadap daya saing perguruan tinggi di Indonesia. Metode yang digunakan dalam tulisan ini adalah Literature Review (Kajian Pustaka). Kajian Pustaka ini dimaksudkan untuk memecahkan suatu masalah yang pada dasarnya bertumpu pada penelaahan kritis dan mendalam terhadap bahan-bahan pustaka yang relevan. Berdasarkan kajian yang dilakukan maka diperoleh hasil bahwa aspek Kepemimpinan (leadership) sebagai driving force untuk menggerakkan Kekuatan Daya Saing (competitiveness strengths) perguruan tinggi dalam rangka memenangkan Area Persaingan (competition areas) sehingga dapat memperoleh Hasil Persaingan (competition result) sesuai yang diharapkan baik dari segi kecukupan kualitas dan kuantitas mahasasiswa, pendapatan yang layak, penghormatan sosial dan budaya terhadap organisasi dan citra yang baik.
\end{abstract}

Kata kunci: kepemimpinan, kekuatan kompetitif, area kompetisi, hasil kompetisi 


\section{PENDAHULUAN}

\section{Latar Belakang}

Setiap negara di belahan dunia ini pasti mengimpikan masa depan yang gemilang. Masa depan yang gemilang hanya dapat dibangun oleh sumber daya manusia yang berkualitas tinggi dan bukan dari kekayaan sumber daya alamnya. Dalam kaitan dengan itu, Djojohadikusumo (1993) menegaskan bahwa pola dan arah perkembangan ekonomi masyarakat dalam jangka panjang dipengaruhi oleh serangkaian empat faktor dinamika: sumber daya manusia, ilmu pengetahuan dan teknologi, sumber daya alam dan kapasitas produksi yang terpasang. Ke-empat faktor dinamika itu harus dilihat dalam kaitan interaksinya satu dengan yang lainnya. Namun diantaranya peranan sumber daya manusia dan kualitasnya mengambil tempat yang sentral, dilengkapi dengan penguasaannya atas bidang ilmu pengetahuan dan teknologi. Sebab, kedua rupa dinamika ini pada hakikatnya akan menentukan kemampuan masyarakat yang bersangkutan dalam hal pemanfaatan, pemeliharaan dan pengamanan kekayaan alam maupun dalam hal pengelolaan dan perawatan kapasitas produksi terpasang dengan sebaik-baiknya.

Jembatan emas untuk mewujudkan sumber daya manusia yang berkualitas adalah pendidikan. Mengingat pentingnya peran pendidikan bagi kemajuan pembangunan sebuah bangsa, maka tidak mengherankan kalau banyak negara memberikan prioritas pembangunan di sektor pendidikan ini.

Di Indonesia, upaya dalam pembangunan pendidikan juga dilakukan di berbagai jenjang, mulai pendikan dasar, menengah sampai pendidikan tinggi. Semua jenjang ini diharapkan meraih fungsi dan tujuan sebagaimana tertuang dalam Undang-Undang Sistem Pendidikan Nasional Nomor 20 Tahun 2003 (Bab II Pasal 3) fungsi dan tujuan pendidikan di Indonesia adalah: Pendidikan nasional berfungsi mengembangkan kemampuan dan membentuk watak serta peradaban bangsa yang bermartabat dalam rangka mencerdaskan kehidupan bangsa, bertujuan untuk berkembangnya potensi peserta didik agar menjadi manusia yang beriman dan bertakwa kepada Tuhan Yang Maha Esa, berakhlak mulia, sehat, berilmu, cakap, kreatif, mandiri, dan menjadi warga negara yang demokratis serta bertanggung jawab.

Pendidikan tinggi yang merupakan jenjang terakhir dalam pendidikan formal memiliki fungsi yang sangat strategis dalam membawa perubahan suatu bangsa. Dunia pendidikan tinggi tidak hanya dapat menjadi sarana bagi peningkatan kualitas sumber daya manusia, tetapi proses pembelajaran di kampus juga diharapkan menjadi wahana yang sangat penting untuk merubah pola pikir masyarakat dalam menuju terwujudnya masyarakat sipil (civil society) yang demokratis. Namun demikian, timbul pertanyaan, Apakah pendidikan tinggi di Indonesia sudah mampu menunjukkan jati diri yang sesungguhnya? Data statistik Direktorat Jenderal Pendidikan Tinggi Departemen Pendidikan Nasional mencatat bahwa secara kuantitas perkembangan perguruan tinggi (akademi, politeknik, sekolah tinggi, istitut dan universitas) di Indonesia meningkat tajam, jika pada bulan September 1999 jumlah lembaga pendidikan tinggi di Indonesia berjumlah 1.634 kemudian jumlahnya naik menjadi 2.428 atau naik sebesar 49\% selama lima tahun terakhir (1999-2004). Kalau jumlah lembaga pendidikan tinggi itu dibedakan menurut statusnya, maka jumlah Perguruan Tinggi Negeri (PTN) naik dari 77 menjadi 81 (atau naik sebesar 5,2\%), tahun 2006 menjadi 82 PTN dan Perguruan Tinggi Swasta (PTS) naik dari 1.557 menjadi 2.347 (atau naik sebesar 51,4\%) dalam periode waktu tersebut, bahkan pada tahun 2006 telah menjadi 2.679 PTS. Jumlah mahasiswa PTN pada tahun 2004 mencapai 880 ribu termasuk mahasiswa Universitas Terbuka, sementara jumlah mahasiswa PTS mencapai 1, 7 juta.

Kualitas dan relevansi lulusan pendidikan tinggi, masih menjadi faktor utama lemahnya daya saing bangsa di kancah perdagangan bebas. Terpuruknya ekonomi bangsa ini, disebabkan oleh rendahnya mutu sumber daya manusia (SDM) yang mengelola sumber ekonomi. Sumber daya 
manusia merupakan salah satu faktor kunci dalam reformasi ekonomi, yakni bagaimana menciptakan SDM yang berkualitas dan memiliki keterampilan serta berdaya saing tinggi dalam persaingan global yang selama ini kita abaikan. Menurut Damanhuri (2003), dalam kaitan tersebut setidaknya ada dua hal penting menyangkut kondisi SDM Indonesia, yaitu: Pertama adanya ketimpangan antara jumlah kesempatan kerja dan angkatan kerja. Jumlah angkatan kerja nasional pada krisis ekonomi tahun pertama (1998) sekitar 92,73 juta orang, sementara jumlah kesempatan kerja yang ada hanya sekitar 87,67 juta orang dan ada sekitar 5,06 juta orang penganggur terbuka (open unemployment). Angka ini meningkat terus selama krisis ekonomi yang kini berjumlah sekitar 8 juta. Kedua, tingkat pendidikan angkatan kerja yang ada masih relatif rendah. Struktur pendidikan angkatan kerja Indonesia masih didominasi pendidikan dasar yaitu sekitar 63,2 \%. Kedua masalah tersebut menunjukkan bahwa ada kelangkaan kesempatan kerja dan rendahnya kualitas angkatan kerja secara nasional di berbagai sektor ekonomi. Indonesia dalam kancah persaingan global menurut World Competitiveness Report menempati urutan ke-45 atau terendah dari seluruh negara yang diteliti, di bawah Singapura (8), Malaysia (34), Cina (35), Filipina (38), dan Thailand (40).

Masih rendahnya kemampuan perguruan tinggi Indonesia dalam menghasilkan keluaran sumber daya manusia yang berkualitas berawal pada kondisi perguruan tinggi yang tidak memiliki kemampuan dalam memformulasi kurikulum pendidikan yang sesuai dengan kebutuhan pasar. Selain itu, peran pemerintah dalam mengeluarkan kebijakan yang terintegrasi untuk terciptanya link and match antara perguruan tinggi dengan dunia usaha belum sepenuhnya dijalankan. Data Direktorat Jenderal Pendidikan Tinggi Departemen Pendidikan Nasional (Kompas, 6 Februari 2008) menjelaskan bahwa jumlah sarjana menganggur melonjak drastis dari 183.629 orang pada tahun 2006 menjadi 409.890 orang pada tahun 2007, ditambah dengan pemegang gelar diploma I, II dan III yang menganggur berdasarkan pendataan tahun 2007 lebih dari 740.000 orang. Kondisi ini jelas telah terjadi mismatch atau ketidaksesuaian antara lulusan perguruan tinggi dan kualifikasi yang dibutuhkan sektor industri dan jasa di masyarakat, akibatnya timbul masalah ketika lulusan perguruan tinggi tersebut ingin mencari pekerjaan.

Membangun daya saing perguruan tinggi guna meningkatkan daya saing sumber daya manusia perlu dikerjakan oleh semua pihak. Pemerintah, perguruan tinggi dan dunia usaha serta masyarakat perlu membagi peran masing-masing dalam memformulasikan kerangka strategik daya saing perguruan tinggi dalam periode jangka panjang. Mengingat dalam era persaingan yang sangat ketat dewasa ini, masing-masing perguruan tinggi harus memiliki competitive distinctive yang membedakan dengan perguruan tinggi lainnya dan juga perlu pula memiliki comparative advantages atau kemampuan daya saing bila dibandingkan dengan perguruan tinggi lainnya baik di dalam maupun di luar negeri.

Beberapa peneliti yang telah melakukan penelitian tentang daya saing perguruan tinggi adalah Cyert (1993), yang menyatakan terdapat tiga aspek yang memiliki pengaruh pada daya saing perguruan tinggi, yaitu: (1) pendidikan; (2) riset; dan (3) perilaku internal manajemen. Selain itu, Elmuti et al (2005) menyatakan bahwa daya saing perguruan tinggi dapat ditingkatkan melalui strategi aliansi antara perguruan tinggi dengan perusahaan. Hal yang sama seperti yang diungkapan oleh Lindelof \& Lofsten (2004) yang menyatakan kerja sama antara perusahaan dengan perguruan tinggi melalui konsep New Technology Based Firms (NTBF) akan mampu memberikan daya saing bagi keduanya. Sedangkan Ham \& Hayduk (2003) menyatakan bahwa daya saing perguruan tinggi dapat dilakukan melalui penekanan gap antara harapan dan persepsi atas kualitas pelayanan.

Beberapa faktor daya saing perguruan tinggi yang telah dikemukakan di atas adalah merupakan Competitiveness Strengths (kekuatan daya saing). Walaupun organisasi telah memiliki kekuatan daya saing namun jika potensi ini tidak digerakkan maka tidak akan berarti apa-apa bagi organisasi, oleh karena itu dibutuhkan seorang pemimpin yang mampu menjadi driving force atau kekuatan penggerak yang mengelola segala potensi yang dimiliki organisasi untuk menampilkan kinerja yang unggul. Jika kekuatan daya saing organisasi ini mampu dikelola oleh pemimpin dengan 
kinerja yang unggul maka organisasi akan memenangkan area persaingan (competition areas). Area persaingan dalam perguruan tinggi ini seperti bersaing dalam memperebutkan calon mahasiswa, penawaran pelatihan-pelatihan kepada masyarakat dan industri, jasa konsultasi bagi organisasi, hibah penelitian, mempertahankan mahasiswa yang ada dan mendorong untuk melanjutkan ke jenjang yang lebih tinggi. Posisi area persaingan yang dikuasai atau telah diperoleh perguruan tinggi akan menghasilkan competition result (hasil persaingan) berupa kecukupan kualitas dan kuantitas mahasiswa, pendapatan yang lebih mendukung (more favorable income atau higher income), respek sosial dari masyarakat dan citra yang terbentuk.

Mengingat posisi pemimpin perguruan tinggi yang sangat penting tersebut maka untuk menghadapi tantangan yang sangat berat ke depan, bagi perguruan tinggi perlu kiranya untuk mempersiapkan pemimpin yang mempunyai integritas kepribadian yang dapat menjadi teladan, pro aktif dalam mengantisipasi lingkungan eksternal yang sangat dinamis dengan menggerakkan seluruh potensi resources yang dimiliki baik yang bersifat tangible maupun intangible melalui pembentukan brand image yang dapat menjamin bagi terbangunnya kepercayaan seluruh stakeholder. Jika kondisi ini bisa dicapai maka keberlanjutan perguruan tinggi dapat terus dipertahankan.

Berdasarkan pemikiran dan fakta empiris yang telah disampaikan di atas maka tulisan ini akan melakukan kajian terhadap peran kepemimpinan sebagai kekuatan untuk meningkatkan daya saing perguruan tinggi. Pendekatan yang dilakukan untuk menjawab permasalahan yang telah dikemukakan di atas adalah melalui metode Literature Review (Kajian Pustaka).

\section{Tinjauan Pustaka}

Menurut Gaffar (Soegoto, 2008) menjelaskan lebih jauh bahwa perguruan tinggi dengan misi yang diembannya, yakni pendikan dan pengajaran, penelitian dan pengembangan, serta pengabdian kepada masyarakat, seyogianya memberikan kontribusi yang fungsional dalam menjawab permasalahan yang dihadapi masyarakat. Sejalan dengan itu, pengembangan ilmu pengetahuan dan teknologi di lingkungan perguruan tinggi dilakukan melalui kegiatan tridharma sesuai dengan kebutuhan pembangunan sekarang dan masa depan. Kehidupan kampus harus dikembangkan sebagi lingkungan masyarakat ilmiah yang dinamis, berwawasan budaya bangsa yang plural, bermoral dan berkepribadian Indonesia. Kiprah perguruan tinggi juga harus dipusatkan pada optimalisasi kontribusi terhadap upaya peningkatan kualitas hidup dan kehidupan bangsa Indonesia, pengembangan ilmu pengetahuan dan teknologi, kehidupan kebudayaan dan identitas kebangsaan. Dengan demikian, perguruan tinggi akan tampil sebagai pemuka dalam pengembangan peradaban bangsa, yang pada gilirannya menjadi andalan seluruh bangsa ini. Kiprah ini meletakkan perguruan tnggi sebagai titik strategis pembangunan nasional dan sebagai asset nasional yang harus terus tumbuh dan berkembang.

Menurut Kerr (Alma, 2005) untuk menggerakkan roda organisasi perguruan tinggi maka diperlukan pemimpin yang betul-betul berkualifikasi baik. Pemimpin perguruan tinggi dalam hal ini Rektor mempunyai tanggung jawab yang istimewa karena harus berperan sebagai leader, educator, creator, initiator, wielder of power, pump, dan juga sebagai office holder, caretaker, inheritor, concensus seeker dan persuader. Menurut Sallis (1993) di sebuah perguruan tinggi, faktor kepemimpinan merupakan salah satu kunci utama untuk mencapai keberhasilan, disamping program, ketersediaan sumber daya, budaya akademik, dan faktor lainnya. Berbuat untuk mencapai yang terbaik di bidangnya, dalam kehidupan kampus yang meritokratik, diperlukan corak kepemimpinan yang unik. Berbeda dengan kepemimpinan di dunia politik, industri dan birokrasi, dalam dunia akademik diperlukan pemimpin yang memiliki keseimbangan kemampuan akademik, kemampuan manajerial dan kemampuan kepemimpinan. Faktor kunci yang menentukan kualitas pendidikan adalah faktor kepemimpinan. Keefektifan pola kepemimpinan, mulai dari tingkat universitas sampai kepada jurusan/ program studi sangat menentukan keefektifan sebuah perguruan tinggi. Kepemimpinan dalam konteks perguruan tinggi adalah kepemimpinan akademik. Secara umum kepemimpinan dapat diartikan 
sebagai kemampuan seseorang untuk mempengaruhi atau memotivasi pihak lain melakukan sesuatu untuk mencapai tujuan tertentu, sedangkan kepemimpinan akademik dapat diartikan sebagai kemampuan seseorang untuk memahami dan memberdayakan kekuatan universitas dalam pelaksanaan Tridarma Perguruan Tinggi. Untuk itu, seorang pemimpin akademik pada semua tingkat organisasi harus memiliki visi dan kemampuan bekerja sama dengan civitas akademika, staf administrasi dan mitranya dalam mengkomunikasikan visi lembaganya. Tanpa kemampuan ini proses perbaikan berkesinambungan sebagai salah satu pilar peningkatan kualitas pendidikan akan sangat sulit tercapai.

Dalam pemimpin organisasi seorang pemimpin perguruan tinggi harus mampu menggerakkan kekuatan organisasi yang dimilikinya untuk bersaing dalam industri yang sama. Kekuatan organisasi ini harus menjadi kekuatan daya saing (Competitiveness Strengths) dalam memenangkan persaingan. Menurut Brodjonegoro (2004) untuk meningkatkan daya saing dan mutu perguruan tinggi, maka perlu diupayakan adanya indikator kinerja perguruan tinggi, yang untuk sementara dapat dinyatakan dalam: (1) kuantitas dan kualitas serta relevansi lulusan; (2) kuantitas dan kualitas serta relevansi hasil penelitian dan pengembangan; dan (3) kuantitas dan kualitas dan relevansi kegiatan pengabdian pada masyarakat.

Kekuatan daya saing (competitiveness strengths) dapat diukur melalui penilaian kinerja perguruan tinggi, seperti yang diungkapkan Miller (1980) yang menyatakan 10 elemen yang dapat dijadikan penilaian pada perguruan tinggi, yaitu: (1) goal and objectives, (2) student learning, (3) faculty performance, (4) academic programs, (5) institutional support services, (6) administrative leadership, (7) financial management, (8) governing board, (9) external relations, (10) institutional self-improvement.

Agar dapat memenangkan persaingan, kompetensi yang dimiliki oleh perguruan tinggi harus memberikan kontribusi yang penting dan besar terhadap nilai-nilai konsumen. Oleh karena itu pengelola perguruan tinggi bertanya-tanya nilai-nilai apa yang diharapkan oleh konsumen pada jasa yang diberikan, apa yang sebenarnya dibayar oleh konsumen, apa sebab konsumen mau membayar lebih pada jasa yang diberikan dan nilai manakah yang menjadi komponen terpenting bagi konsumen sehingga mereka mau membayar lebih. Kompetensi itu harus unik dan bermutu, tidak dapat ditiru dengan mudah oleh para pesaing dan para konsumen memberikan nilai tinggi pada kompetensi yang dimiliki oleh perguruan tinggi. Bertitik total dari konsep persaingan industri (Porter, 1993), dalam dunia pendidikan, lima kekuatan dalam persaingan itu dapat diterjemahkan sebagai: (a) Munculnya perguruan tinggi baru, termasuk perguruan tinggi asing yang membuka cabangnya di Indonesia atau kerjasama antara asing dan lokal; (b) Dibukanya jurusan atau program studi baru oleh perguruan tinggi lainnya lebih menarik dan sesuai kebutuhan pasar; (c) Terjadinya perubahan dan peningkatan kebutuhan dari masyarakat pengguna lulusan perguruan tinggi terhadap kompetensi yang dihasilkan oleh perguruan tinggi; (d) Terjadinya perubahan dan peningkatan kebutuhan dari para calon mahasiswa/orang tua mahasiswa atas jenis dan layanan pendidikan yang dikehendaki; (e) Ancaman persaingan dari perguruan tinggi yang sudah ada.

Arena persaingan (Competition Areas) yang diperebutkan oleh perguruan tinggi saat ini tidak hanya calon konsumen dalam hal ini mahasiswa tetapi juga unsur lainnya. Menurut Duderstadt (2003) kebanyakan universitas sangat bergantung kepada beberapa sumber pendapatan yaitu: tuition and fees paid by student, state appropriations, federal research grants and contracts, gift and endowment income dan auxiliary activities (seperti rumah sakit, residence halls dan athletics). Jika arena persaingan sudah dapat dimenangkan oleh perguruan tinggi maka perguruan tinggi yang bersangkutan akan menikmati hasil dari kemenangan persaingan (Competition Result) berupa kecukupan dalam kualitas dan kuantitas mahasiswa (Adequacy Quality and Quantity Student), keuangan yang mencukupi untuk operasional organisasi (Favorable income), memperoleh penghargaan sosial dari masyarakat (Social Cultural Respect) dan pada akhirnya akan membentuk citra (Image) yang positif bagi perguruan tinggi yang bersangkutan. Tentu saja semua perguruan tinggi menginginkan citra postif yang terus menerus untuk menjamin keberlangsungan organisasi. 
Pada tahun-tahun mendatang, perguruan tinggi Indonesia akan menghadapi berbagai tantangan besar yang perlu dan harus direspons dengan strategis. Globalisasi ekonomi dan revolusi teknologi informasi adalah dua kekuatan besar yang sangat mempengaruhi dunia perguruan tinggi Indonesia. Jika perguruan tinggi tidak mampu mengantisipasi tantangan globalisasi dengan memadai, diperkirakan lembaga tersebut tidak mampu mempertahankan eksistensinya. Oleh karena itu perlu bagi perguruan tinggi di Indonesia untuk terus meningkatkan kekuatan daya saingnya agar tetap mampu bertahan.

\section{METODE PENELITIAN}

Metode yang digunakan dalam tulisan ini adalah literature review (kajian pustaka). Kajian Pustaka ini dimaksudkan untuk memecahkan suatu masalah yang pada dasarnya bertumpu pada penelaahan kritis dan mendalam terhadap bahan-bahan pustaka yang relevan. Telaah pustaka dilakukan dengan cara mengumpulkan data atau informasi dari berbagai sumber pustaka yang diperlukan sebagai sumber ide untuk menggali pemikiran atau gagasan baru, sebagai bahan dasar untuk melakukan deduksi dari pengetahuan yang sudah ada, sehingga kerangka teori baru dapat dikembangkan, atau sebagai dasar pemecahan masalah.

Sumber-sumber pustaka yang dikaji dalam tulisan ini berupa buku, hasil penelitian, jurnal dan artikel ilmiah lainnya. Langkah-langkah pembuatan literature review, yaitu: (1) menetapkan sumbersumber untuk bahan literature review yang sesuai dengan topik kajian tulisan ini; (2) mengevaluasi isi yang dimuat di dalam sumber-sumber studi pustaka yang ditetapkan. Pada bagian ini dapat dimuat halhal yang berkaitan dengan anggapan-anggapan dasar atau fakta-fakta yang dipandang benar tanpa adanya verifikasi dan keterbatasan, yaitu aspek-aspek tertentu yang dijadikan kerangka berpikir. Analisis ini diperlukan untuk menyusun alur berpikir dalam memecahkan masalah; (3) membuat summary terhadap isi sumber-sumber studi pustaka; (4) menggali pemikiran dan gagasan baru terhadap topik yang menjadi bahan kajian untuk menetapkan positioning konsep sebagai bahan penelitian berikutnya.

\section{HASIL DAN PEMBAHASAN}

Dalam dekade terakhir ini, pendidikan tinggi di Indonesia mengalami perubahan paradigma yang cukup signifikan. Perubahan paradigma yang dimaksud adalah meliputi perubahan paradigma pengelolaan persaingan. Perubahan ini terpicu oleh perkembangan lingkungan eksternal yang sangat dinamis menyangkut perkembangan teknologi informasi, sehingga e-learning, e-university dan sejenisnya mulai banyak dibicarakan dan diusahakan. Perubahan pengelolaan menyangkut badan penyelenggara pendidikan tinggi, baik yang diselenggarakan pemerintah maupun swasta. Kemudian masuknya perguruan tinggi luar negeri memeriahkan persaingan yang ada di dalam negeri. Perguruan tinggi tidak hanya perlu dilihat sebagai pusat ilmu pengetahuan, pusat penelitian dan pusat pengabdian masyarakat, tetapi juga suatu entitas korporat penghasil ilmu pengetahuan yang perlu bersaing untuk menjamin kelangsungan hidup. Persaingan sebagaimana dialami oleh organisasi profit (perusahaan), meliputi persaingan di bidang mutu, harga dan layanan. Perguruan tinggi sebagai suatu entitas non profit, menghadapi hal yang sama pula. Pengelolaan semuanya memerlukan pengetahuan dan keterampilan manajemen yaitu manajemen perguruan tinggi. Anggapan bahwa organisasi non profit dapat dikelola apa adanya karena tidak perlu menghasilkan keuntungan adalah pendapat yang keliru. Sejalan dengan itu seperti yang diungkapkan oleh Drucker (1990) bahwa: Dua puluh tahun yang lalu, manajemen merupakan dunia yang kotor bagi mereka yang terlibat dalam organisasi nirlaba. Manajemen dianggap bisnis, dan nirlaba bangga terhadap diri mereka yang bebas dari noda 
komersialisme dan menjauhi pertimbangan-pertimbangan kotor karena apa yang mereka pegang teguh. Sekarang, kebanyakan dari mereka mempelajari bahwa nirlaba membutuhkan manajemen, bahkan lebih dari yang dilakukan bisnis, dan alasan yang paling mendasar karena mereka kehilangan disiplin atas berbagai hal penting yang mereka pegang teguh.

Dalam kaitannnya dengan makna perguruan tinggi, Indrajit \& Djokopranoto (2006) menegaskan bahwa sekurang-kurangnya ada empat atau lima dimensi makna yang melekat pada perguruan tinggi, yaitu (1) dimensi keilmuan (ilmu dan teknologi); (2) dimensi pendidikan; (3) dimensi sosial (kehidupan masyarakat); dan (4) dimensi korporasi (satuan pendidikan atau penyelenggara). Di atas semua itu, apabila pendidikan tinggi dimaksudkan untuk meningkatkan martabat manusia, maka dapat diangkat ke dalam dimensi makna yang lebih mendalam, yaitu (5) dimensi etis. Sebagaimana diketahui bahwa Struktur atau Bentuk Organisasi, Visi dan Misi Perguruan Tinggi/Universitas, masyarakat Indonesia telah mengambil alih dari masyarakat budaya Renaissance di Eropa. Salah satu nara sumber adalah pemikiran Cendekiawan terpelajar Wilhelm Von Humboldt, yang merupakan pendiri dari Universitas Von Humboldt di kota Berlin Jerman (Nasution, 2004).

Ciri-ciri yang terpenting dari pemikiran mengenai Bentuk Organisasi, Visi \& dan Misi suatu Universitas, adalah pembinaan berbagai disiplin-disiplin Ilmu Pengetahuan yang agak sangat spesialistis, berbentuk berbagai institusi-institusi yang dinamakan leerstoel (kursi pengajaran). Berbagai leerstoel-leerstoel inilah bersatu terorganisasi menjadi suatu universitas, yang tugas-tugasnya adalah melaksanakan pengajaran yang terkait erat dengan penelitian. Pada waktu itu memang universitas merupakan fasilitas pendidikan tinggi, hanya bagi para lapisan elite/atas masyarakat, yang dibiayai sepenuhnya oleh pemerintah. Sehingga memang Universitas agak terpisah atau menjaga jarak dengan kehidupan hiruk-pikuk aktivitas masyarakat dalam bidang politik, sosial ekonomi dan pemerintah. Seluruh pengajaran dan penelitian ditujukan untuk mengejar Kebenaran \& Ilmu Pengetahuan, demi mengembangkan kekuatan moral manusia dan memberdayakan budi manusia. Kehidupan yang agak terisolasi dan hiruk-pikuk kehidupan Politik, sosial dan ekonomi masyarakat, sering disebut sebagai falsafah Menara Gading atau Ivory Tower Philosophy, demi usaha-usaha yang tekun dan sungguh-sungguh mengejar kebenaran dan ilmu pengetahuan tadi tidak terganggu.

Kampus Universitas Stanford dan Massachusetts Institute of Technology (MIT) di Amerika yang pertama-tama meninggalkan Ivory Tower Philosophy dan membangun inkubator-inkubator yang dapat melahirkan dan membina industri-industri mula (start up company) high tech, yang berbasis atas penemuan para mahasiswa dan dosen-dosennya di dalam kampus. Industri-industri kecil baru dalam bidang Electronic dan bidang Biotech dan beberapa bidang atau disiplin lainnya dengan cepat berkembang dan sangat memperkuat pertumbuhan Ekonomi nasional Amerika.

Kira-kira 4000 perusahaan baru telah didirikan oleh alumni dan dosen-dosen MIT, dan jika penghasilan seluruhnya dijumlahkan, maka penghasilan ini merupakan produktivitas suatu negara yang ke 24 terkaya didunia, yaitu US\$ 230 billion setiap tahunnya, dan mempekerjakan satu juta orang. $50 \%$ dari industri-industri tersebut dibangun dalam 15 tahun sesudah hari wisuda pendiri, dan $15 \%$ dalam jangka waktu 5 tahun sesudah hari wisuda pendirinya.

Hampir semua Universitas diseluruh dunia berusaha meniru Stanford University dan MIT, dan berusaha membangun inkubator-inkubator di dalam kampus masing-masing. Ivory Tower Philosophy dari budaya Renaissance ditinggalkan. Seluruh Universitas di seluruh Dunia sangat tertarik, melihat kampus Amerika mampu mengaitkan (meng-synergy-kan) disiplin academic-science dengan corporate-science. Seluruh dunia kagum melihat Amerika dapat mengkombinasikan daya juang meneliti seorang ilmuwan dengan nilai/sifat berani mengambil risiko seorang Wirausahawan.

Demikian juga seluruh dunia kagum, dengan kemampuan Universitas Stanford dan MIT, membuat banyak penemuan ilmu pengetahuan yang di patent-kan, melahirkan/mencetak banyak wirausaha-wirausahawan baru, sambil juga mengumpulkan beberapa hadiah-hadiah Nobel, dan tetap 
masih mampu turut berpartisipasi menggerakan kekuatan moral dan kekuatan intelektual kampus, untuk mengkritik atau menyetop perang Vietnam yang lalu. Sebagai koreksi yang berani dan sangat bijaksana, terhadap kekeliruan yang dilakukan Pemerintah-nya sendiri yang pada hakekatnya adalah yang membiayai seluruh dosen/mahasiswa dan aktivitas Universitas itu sendiri.

Memang di Zaman Industrial-Age manusia sudah hakul yakin, bahwa bahwa inovasi muncul dan tumbuh melalui suatu garis lurus, dari riset dasar yang dilakukan di dalam Universitas-universitas, melaui riset terapan di dalam perusahaan swasta, lalu baru sampai ke bidang ekonomi nasional pada umumnya. Namun di dalam Knowledge-Age dan Information-Age sekarang ini, perkembangan dan penelitian ilmu pengetahuan tidak lagi berurut sederhana sebagai suatu garis lurus, tetapi justru langsung menyelesaikan banyak persoalan-persoalan yang kompleks, yang melalui, memotong, dan/atau melompat lintas batas-batas berbagai disiplin ilmu sekaligus. Fenomena yang digambarkan tersebut mendorong perguruan tinggi meng-adaptasi bentuk organisasi, beserta Visi dan Misi perguruan tinggi, kearah keterkaitan (networking) semua disiplin-disiplin yang tercakup dalam seluruh budidaya manusia, sambil meninggalkan falsafah menara gading yang memang sudah ditinggalkan oleh praktis semua universitas di seluruh dunia.

Keunggulan bersaing adalah jantung dari kinerja perusahaan di dalam pasar yang bersaing. Tingginya persaingan bisnis yang terjadi di dunia ini menuntut setiap perusahaan untuk saling meluncurkan berbagai produk dan jasa yang memiliki daya saing yang tinggi. Perusahaan yang memiliki daya saing tinggi adalah perusahaan yang mampu meluncurkan produk baru secara cepat dengan periode waktu pengembangan produk yang singkat.

Menurut Lindelof \& Lofsten (2004), dalam mengkaji konsep daya saing tidak terlepas dengan konsep strategi, karena strategi mengandung pengertian peningkatan daya saing (melalui pengembangan produk, kompetisi harga, pengembangan teknologi, menganalisis perilaku pesaing dan lainya) yang dilakukan melalui positioning analysis dimana bisnis perusahaan akan dijalankan, di wilayah mana persaingan, dan melakukan resource base-analisys bagaimana perusahaan akan bersaing. Daya saing (competitive advantage) didefinisikan oleh Grant (1991) sebagai hasil atas pemahaman secara menyeluruh dari aspek eskternal dan internal yang memberikan pengaruh kuat terhadap perusahaan.

Selain itu, menurut Hitt (2001) bahwa ketika perusahaan mengimplementasikan suatu strategi yang tidak dapat ditiru oleh perusahaan lain atau terlalu mahal untuk menirunya, perusahaan ini memiliki keunggulan persaingan bertahan atau dapat bertahan (sustained atau sustainable competitive advantage, selanjutnya disebut sebagai keunggulan persaingan). Lebih lanjut dikatakan bahwa sebuah perusahaan pasti memiliki keunggulan persaingan hanya setelah usaha perusahaan lain untuk meniru strateginya gagal atau terhenti. Bahkan jika suatu perusahaan mencapai keunggulan persaingan, biasanya ia dapat bertahan hanya untuk periode tertentu. Kecepatan seorang pesaing untuk mendapatkan keahlian yang diperlukan untuk meniru manfaat suatu strategi penciptaan-nilai perusahaan menentukan lamanya keunggulan persaingan dapat bertahan. Pemahaman tentang bagaimana mengeksploitasi keunggulan persaingannya diperlukan bagi perusahaan yang ingin mendapatkan laba di atas rata-rata. Masih diungkapkan oleh pendapat Hitt (2001) bahwa dengan mendapatkan daya saing strategis, dan sukses mengeksploitasi keunggulan persaingannya, suatu perusahaan mampu mencapai tujuan utamanya: mendapatkan laba di atas rata-rata. Laba di atas ratarata adalah kelebihan penghasilan yang diharapkan seorang investor dari investasi lain dengan jumlah risiko serupa. Risiko adalah ketidakpastian investor tentang laba atau rugi yang dihasilkan oleh investasi tertentu.

Jika melihat permasalahan yang ada di perguruan tinggi baik swasta maupun negeri, maka masalah pokoknya dalam persaingan ini ialah bagaimana dapat merebut pasar untuk menjaring calon mahasiswa, sesuai daya tampung yang dimiliki dengan kualitas yang baik. Dengan jumlah mahasiswa pendaftar yang banyak, penyaringan dapat dilakukan lebih baik dan ketat untuk memperoleh sejumlah 
mahasiswa yang berkualitas. Dengan demikian, agar perguruan tinggi dapat menarik calon mahasiswa dan orang tua mahasiswa, perguruan tinggi harus memiliki ciri-ciri sebagai berikut: biaya pendidikan sebanding dengan mutu, dosen bermutu, pelayanan bermutu dan fasilitas yang dimiliki juga bermutu. Selain mahasiswa, area persaingan juga meliputi product knowledge, consultanty, research grant, retaining/continuing student dan international student. Khusus product knowledge, consultanty, research grant merupakan aktivitas yang diharapkan mampu mendorong pendapatan di luar tuition fee.

Terjadinya peningkatan persaingan dalam dunia pendidikan tidak jauh bedanya dengan dalam dunia bisnis. Menurut Ibrahim (dalam Moedjadi, 2005) persaingan dalam dunia bisnis terjadi karena terjadi perubahan lingkungan dan iklim bisnis yang menyebabkan terjadinya perubahan dalam harapan dan kebutuhan pasar konsumen. Perubahan yang terjadi itu antara lain ialah: dari ekonomi stabil menjadi ekonomi yang tidak bisa diduga sebelumnya; dari pasar relatif stabil menjadi pasar mudah berubah dari proteksi dan regulasi menjadi pasar bebas dan deregulasi; dari persaingan domestik menjadi persaingan global. Dari segi manajemen perubahan-perubahan itu ialah: dari organisasi tertutup menjadi organisasi terbuka; dari sumber daya melimpah menjadi sumber daya kualitas terbatas; dari kehandalan otot menjadi kekuatan ilmu dan pengetahuan; dari pemecahan masalah mengandalakan sukses lama dan instuisi menjadi pemecahan masalah berorientasi pada informasi mutakhir. Dari manajer pemilik menjadi manajer profesional; dari perusahaan milik pribadi menjadi milik publik.

Perubahan-perubahan yang disebutkan diatas juga terjadi pada dunia pendidikan, khususnya pendidikan tinggi, perubahan-perubahan itu ialah: (1) dari pengajaran yang berorientasi pada guru (dosen) berubah menjadi berorientasi pada siswa (mahasiswa); (2) dari berorientasi lulus yang sebanyak-banyaknya menjadi lulus dengan keterampilan yang siap terjun ke masyarakat; (3) dari lulusan yang memiliki indeks prestasi kumulatif (IPK) tinggi menjadi lulusan dengan kompetensi tinggi; (4) dari kurikulum yang mengikuti kurikulum pemerintah atau standar menjadi kurikulum yang unik yang merupakan ciri dari lembaga pendidikan itu; (5) dari pelayanan yang menekankan pada ketertiban internal kantor menjadi pelayanan yang berorientasi pada kepuasan pelanggan.

Akibat dari perubahan-perubahan tersebut diatas melahirkan paradigma baru yang perlu dipahami dan diterima, walaupun sulit karena harus mengubah budaya pola pikir yang sudah tertanam berpuluh tahun lamanya. Paradigma baru dalam pengelolaan pendidikan tinggi itu ialah; mengubah dari proses reenginering menjadi penciptaan strategi baru, dari kompetensi pasar menjadi kompetisi pangsa peluang, dari rencana strategik menjadi arsitektur strategik, dari kepemimpinan yang transaksioner menjadi kepemimpinan yang visioner, dari recruitment pegawai berdasarkan atas tingkat pendidikan yang dimiliki menjadi berdasarkan atas kompetensi yang dimiliki, dan dari persaingan yang memperhatikan tingkat lokal menjadi persaingan yang berorientasi global. Secara singkat perubahan-perubahan yang harus kita lakukan untuk menghadapi persaingan ialah: berorientasi global, berorientasi pada mutu, berorientasi pada kepuasan pelanggan, siap mau berubah, merebut peluang pasar, memiliki keunikan sebagai ciri khas lembaga pendidikan dan berwawasan masa depan (Ibrahim dalam Moedjadi, 2005).

Agar dapat memenangkan persaingan, kompetensi yang dimiliki oleh perguruan tinggi harus memberikan kontribusi yang penting dan besar terhadap nilai-nilai konsumen. Oleh karena itu pengelola perguruan tinggi bertanya-tanya nilai-nilai apa yang diharapkan oleh konsumen pada jasa yang diberikan, apa yang sebenarnya dibayar oleh konsumen, apa sebab konsumen mau membayar lebih pada jasa yang diberikan dan nilai manakah yang menjadi komponen terpenting bagi konsumen sehingga mereka mau membayar lebih. Kompetensi itu harus unik dan bermutu, tidak dapat ditiru dengan mudah oleh para pesaing dan para konsumen memberikan nilai tinggi pada kompetensi yang dimiliki oleh perguruan tinggi. 
Usaha untuk berubah, berorientasi untuk kepuasan pelanggan, serta meningkatkan kompetensi adalah usaha-usaha dalam rangka mempertahankan keunggulan kompetitif. Menurut D’Aveni \& Gunther (dalam Winardi, 2003), posisi kompetitif suatu perusahaan, termasuk organisasi pendidikan, perlu dipertahankan selama mungkin. Tetapi perlu diingat, bahwa keunggulan hanya dapat bertahan sampai pihak pesaing meniru dan mengungguli keunggulan dan keunikan yang dimiliki oleh organisasi itu. Untuk menghadapi hal ini agar keunggulan dapat terus bertahan lama, D'Aveni menyarankan diciptakan suatu seri keunggulan temporer. Dengan seri keunggulan jangka pendek demikian, organisasi secara efektif menciptakan suatu keunggulan jangka panjang yang dapat bertahan di pasar. Keadaan ini menurut D’Aveni yang disebut hiper kompetitif.

Menurut Wheelen \& Hunger (2001), strategi bersaing adalah strategi bisnis yang berfokus pada peningkatan posisi bersaing produk dan jasa perusahaan dalam industri atau segmen pasar tertentu yang dilayani perusahaan dan mengatasi masalah bagaimana perusahaan dan unit-unitnya dapat bersaing dalam bisnis dan industri. Sementara itu menurut Rangkuti (2003), keunggulan bersaing merupakan kegiatan spesifik yang dikembangkan oleh perusahaan agar lebih unggul dibandingkan dengan pesaingnya. Lebih jauh Cravens (1996) menjabarkan bahwa mengutip pendapat Day \& Wensley yang mengemukakan bahwa keunggulan bersaing seharusnya dipandang sebagai suatu proses dinamis daripada hasil akhir. Prosesnya terdiri atas sumber keunggulan, keunggulan posisi, dan prestasi hasil akhir suatu investasi laba untuk mempertahankan keunggulan (Gambar 1). Sumber keunggulan bersaing itu adalah: keterampilan, sumber daya dan pengendalian yang superior.

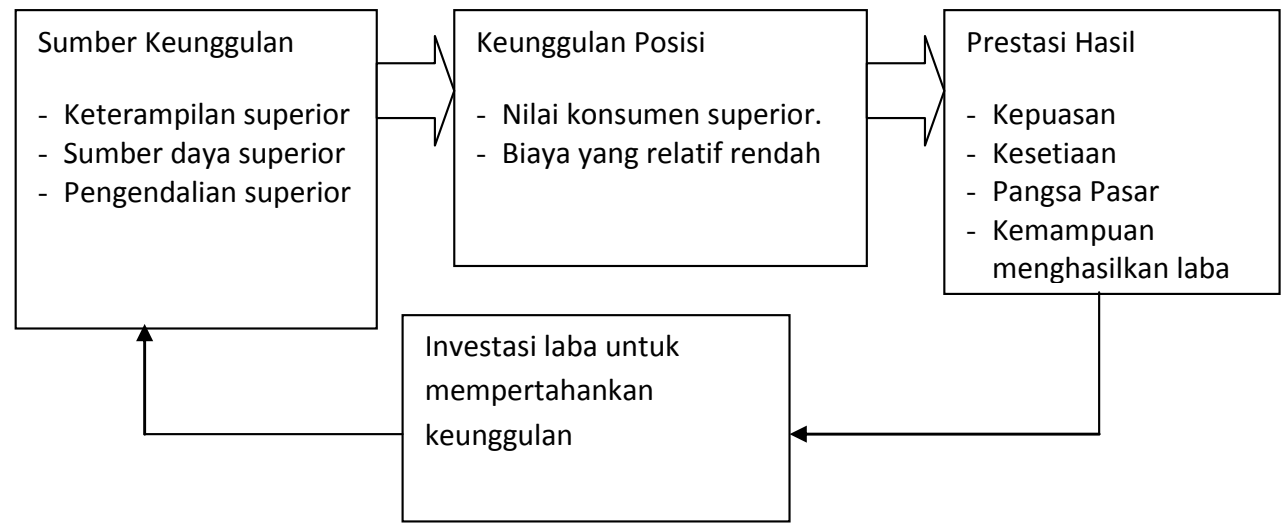

Gambar 1 Proses Keunggulan Bersaing Sumber : Cravens, 1996

Penjelasan mengenai Gambar 1 dapat dijelaskan beberapa poin, yaitu: (1) sumber keunggulan. Analisis keunggulan bersaing menunjukkan perbedaan dan keunikannya di antara para pesaing. Sumber keunggulan bersaing itu adalah: keterampilan, sumber daya dan pengendalian yang superior; (2) keunggulan posisi, keunggulan posisi merupakan hasil produksi dengan biaya rendah (cost leadership) atau diferensiasi yang memberikan keunggulan nilai bagi konsumen. Biaya yang lebih rendah memungkinkan perusahaan memberikan nilai yang superior dengan pemberian harga yang lebih rendah daripada pesaing untuk produk yang sama. Perbedaan penampilan produk yang sesuai dengan preferensi pembeli menghasilkan manfaat unik yang dapat menutupi harga tinggi. Faktor penting dalam mencari keunggulan adalah bagaimana mengambil keputusan dan bersaing; (3) prestasi hasil akhir, pada saat keterampilan organisasi, sumber daya, dan pengendalian digunakan untuk memperoleh nilai dan atau efisiensi biaya, keunggulan posisi telah menuju pada prestasi dari hasil akhir (kepuasan konsumen, kesetiaan terhadap merek, pangsa pasar, dan kemampuan mendapatkan laba); (4) investasi laba, keunggulan bersaing merupakan sarana yang selalu berubah, oleh karena itu harus mempergunakan sebagian labanya untuk mempertahankan keunggulan tersebut. 
Jadi keunggulan bersaing pada dasarnya tumbuh dari nilai atau manfaat yang dapat diciptakan perusahaan bagi para pembelinya yang lebih dari biaya yang harus dikeluarkan perusahaan untuk menciptakannya. Keunggulan bersaing bersumber dari banyak ragam kegiatan yang dilakukan perusahaan dalam mendesain, membuat, memasarkan, mendistribusikan, dan mendukung produknya.

Untuk membangun keunggulan kompetitif berkelanjutan, menurut Walker (2007) yang harus dilakukan oleh organisasi adalah dengan mengoptimalkan resources capabilities, yang terdiri dari value drivers, cost drivers, retaining customers dan preventing imitation. Value drivers dan cost drivers akan menciptakan posisi pasar yang kuat (superior market position), sedangkan retaining customers (mempertahankan konsumen) dan preventing imitation (mencegah imitasi produk) akan mendorong posisi pasar yang mampu bertahan (defendable market position). Jika kedua varianbel ini (superior market position dan defendable market position) mampu dipertahankan maka oleh organisasi pada gilirannya akan dapat mewujudkan keunggulan kompetitif berkelanjutan (sustainable competitive advantage). Penjelasan rinci dapat dilihat pada gambar 2.

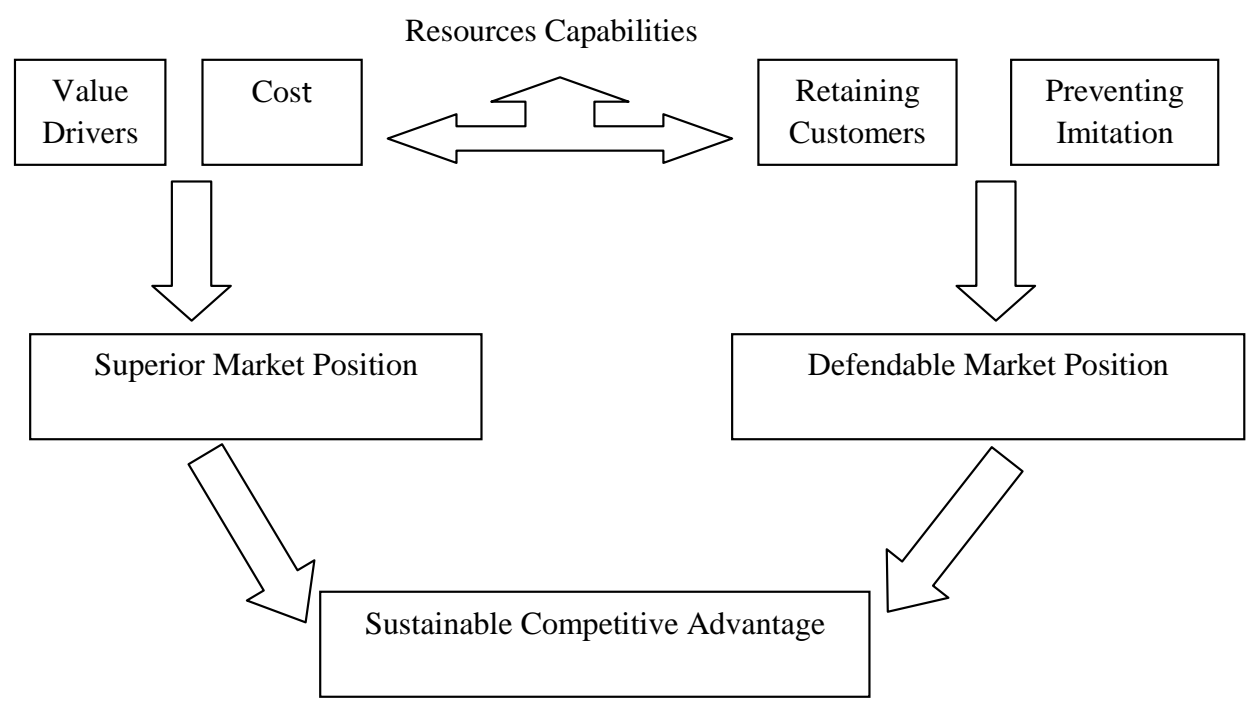

Sumber: Walker, 2007

Gambar 2 Building Sustainable Competitive Advantage

Dengan tingkat persaingan yang ketat antar perguruan tinggi yang ada, maka perguruan tinggi saling bersaing dengan mengunakan taktik dan strategi yang mereka anggap dapat memenangkan persaingan, diantaranya ialah memberikan biaya pendidikan yang kompetitif atau dengan cara pembayaran yang mudah, perang iklan (promosi) melalui media massa, elektronik, atau brosur-brosur yang menjanjikan, menawarkan dan menghasilkan produk-produk baru yang sedang trend di pasar, peningkatan pelayanan melalui kelengkapan dan kemewahan fasilitas pembelajaran. Unjuk kinerja melalui persaingan antar perguruan tinggi ini tentu sepanjang dijalankan berdasarkan etika yang diembannya sebagai lembaga pendidikan, akan sangat menguntungkan calon mahasiswa. Karena calon mahasiswa diberikan berbagai pilihan secara terbuka sesuai dengan minatnya masing-masing.

Kekuatan daya saing perguruan tinggi ditentukan oleh seberapa besar perguruan tinggi tersebut mampu menggerakkan potensi sumber daya yang dimiliki untuk memenangkan persaingan. Pimpinan sebagai pusat manajemen berkewajiban untuk mengarahkan faktor-faktor yang dapat menjadi kekuatan daya saing perguruan tinggi ini agar mampu mempunyai kinerja yang baik. 
Berdasarkan studi yang dilakukan oleh North Central Association of School and Colleges terhadap perguruan tinggi di Amerika Serikat (Jedamus, Peterson \& Association, 1980) mengemukakan beberapa pertimbangan dalam memilih perguruan tinggi adalah melalui penilaian kinerja perguruan tinggi, yang terdiri dari 11 elemen, yaitu: (1) faculty competence, (2) faculty organization, (3) conditions of faculty services, (4) curriculum, (5) instruction, (6) library, (7) induction of students, (8) student personnel service, (9) adminstration, (10) finance, dan (11) physical plant. Secara garis besar studi tersebut memperoleh hasil bahwa hubungan antara institutional excellence dengan faculty organization korelasinya paling tinggi $(r=0,67)$ dan faculty competence mendapatkan korelasi paling rendah $(\mathrm{r}=0,45)$, walaupun hasil itu tetap positif. Hasil lain dalam studi tersebut adalah instruction $(\mathrm{r}=0,65)$, curriculum $(\mathrm{r}=0,64)$, administration $(\mathrm{r}=0,60)$ dan finance $(\mathrm{r}=$ $0,47)$.

Pendapat lainnya dikemukan oleh Miller (1980) yang menyatakan bahwa ada 10 area dan 45 evaluative statement yang merupakan kerangka kerja untuk menilai institusi perguruan tinggi. Kesepuluh area tersebut adalah (1) goal and objectives, (2) student learning, (3) faculty performance, (4) academic programs, (5) institutional support services, (6) administrative leadership, (7) financial management, (8) governing board, (9) external relations, (10) institutional self-improvement.

Setelah rencana dan struktur organisasi ditetapkan, orang-orangnya ditentukan, langkah selanjutnya adalah membuat bagaimana semua sumber daya manusianya bekerja untuk mencapai tujuan organisasi. Pimpinan organisasi berkewajiban memimpin organisasi, menggerakkan, mengarahkan, dan memotivasi orang-orang atau semua anggota organisasi, dan mengadakan komunikasi dengan mereka. Pada umumnya pengarahan merupakan kegiatan manajemen yang paling menantang dan sangat penting karena langsung berhadapan dengan orang atau anggota organisasi.

Bagaimana membuat anggota organisasi bekerja untuk mencapai tujuan organisasi merupakan pekerjaan yang tidak mudah, bahkan rumit. Pimpinan organisasi memotivasi semua anggota organisasi untuk bekerja secara optimal. Bagaimana pimpinan organisasi membuat sintesis baru dari situasi dan fenomena yang sulit dan rumit tadi, sehingga semua potensi yang ada di dalam organisasi dapat digerakkan dan diarahkan untuk keuntungan organisasi, pimpinan organisasi, dan semua anggota organisasi strategi yang paling sederhana, paling murah, dan paling realistis adalah menjadi manajer yang efisien sekaligus menjadi pemimpin yang efektif. Schermerhorn (1999) menyatakan bahwa: pengarahan adalah proses untuk menumbuhkan semangat para karyawan supaya giat bekerja serta membimbing mereka melaksanakan rencana dalam mencapai tujuan organisasi. Dengan pengarahan, pimpinan organisasi menciptakan komitmen, mendorong usaha-usaha yang mendukung tercapainya tujuan organisasi, dan mempengaruhi anggota organisasi supaya melakukan yang terbaik untuk kepentingan organisasi. Karena semua organisasi berisi orang-orang, maka merupakan tugas pimpinan organisasi untuk mengarahkan dan mengkoordinasi orang-orang ini. Inilah fungsi mengarahkan orangorang lain, memilih saluran komunikasi yang paling efektif, atau memecahkan konflik antara anggotaanggotanya, berarti mereka sedang memimpin.

Persepsi seseorang tentang kepemimpinan yang berbeda-beda menyebabkan beragamnya teori-teori tentang kepemimpinan. Hal ini bisa dilihat dari pengertian kepemimpinan yang sangat variatif. Bahkan Stogdil (Yukl, 1998) menyimpulkan bahwa terdapat hampir sama banyaknya definisi kepemimpinan dengan jumlah orang yang mencoba mendefinisikannya. Namun dari definisi-definisi mengenai kepemimpinan, mencerminkan asumsi bahwa kepemimpinan menyangkut sebuah proses pengaruh sosial yang sengaja dijalankan seseorang terhadap orang lain untuk mengorganisir aktivitasaktivitas serta hubungan-hubungan di dalam sebuah kelompok atau organisasi.

Menurut Yukl (1998) dalam melihat kepemimpinan lebih mementingkan keinginan orang yang dipengaruhi oleh pimpinan daripada keinginan pemimpin itu sendiri. Seorang disebut pemimpin bukan karena ia membuat orang lain mengikuti keinginannya atau memaksakan orang mengikuti keinginannya, melainkan karena dapat membuat orang lain dapat melakukan apa yang ia inginkan. 
Selanjutnya Bennis \& Nanus (1995) mendefinisikan kepemimpinan dari sudut pandang pemimpin. Menurutnya seseorang disebut pemimpin, jika ia mampu memberi visi kepada organisasi dan mampu menjabarkannya menuju realita. Perpaduan sudut pandang ditemukan dalam definisi Burns (dalam Yukl, 1998). Ia menggambarkan kepemimpinan sebagai sesuatu hubungan timbal balik yang selalu berkembang. Dalam hubungan yang demikian para pemimpin terus menerus membangkitkan motivasi berbagai respon pengikat dan memodifikasi perilaku mereka bila menghadapi sikap responsif ataupun perlawanan dalam proses hubungan maupun feedback yang berlangsung secara continue.

Selanjutnya, pimpinan organisasi juga wajib memberikan motivasi anggotanya, menggerakkan kegiatan-kegiatan lainnya, menyeleksi jalur komunikasi yang efektif, dan menyelesaikan konflik diantara para anggota organisasi. Dari banyaknya fungsi dan tugas pemimpin, memotivasi anggota organisasi merupakan tugas yang perlu diprioritaskan seorang pemimpin, karena motivasi merupakan sesuatu yang mendorong seseorang bertindak atau berperilaku tertentu. Menurut Hanafi (1997), motivasi membuat seseorang memulai, melaksanakan dan mempertahankan kegiatan melalui orang lain. Dalam hal ini perlu disadari bahwa pemimpin adalah seseorang yang mencapai tujuan organisasi dengan menggunakan orang lain (getting things done through the others). Pimpinan organisasi tidak bekerja sendiri. Dengan demikian, memahami motivasi anggota organisasi, yang mendorong seseorang bertindak atau bekerja, sangat penting dilakukan pimpinan organisasi. Pemahaman tersebut merupakan kunci mendorong orang lain mengerjakan keinginan pimpinan organisasi agar tujuan organisasi tercapai. Hal ini berarti bahwa motivasi merupakan faktor penting yang mendukung prestasi kerja. Meskipun demikian, harus diakui bahwa motivasi bukan satu-satunya pendukung prestasi kerja. Prestasi kerja seseorang juga tergantung dari faktor lainnya yaitu kemampuan (ability) dan persepsi peranan (role perception). Kemampuan yang baik, persepsi peranan yang tepat, dan motivasi yang tinggi merupakan kunci prestasi kinerja.

Tingkat penggunaan kekuasaan sangat berbeda dari satu pemimpin ke pemimpin lainnya. Hal ini disebabkan setiap organisasi merupakan suatu satuan kerja yang mempunyai ciri-ciri, kondisi, kepribadian, sistem nilai, keyakinan, etos kerja, dan masalah yang sifatnya khas. Karena setiap organisasi bersifat unik, maka penggunaan kekuasaan oleh pimpinan organisasi harus disesuaikan dengan keunikan dan kekhasan organisasi yang dipimpinnya. Salah satu aspek organisasi yang unik adalah kultur yang dianut dan berlaku bagi semua anggota organisasi dalam organisasi itu. Kultur itulah yang membedakan satu organisasi dari organisasi lain, meskipun bergerak dalam kegiatan yang sejenis.

Kepemimpinan sebagai daya saing merupakan kepemimpinan transformasional, yang merupakan perluasan dari kepemimpinan kharismatik, pemimpin menciptakan visi dan lingkungan yang memotivasi para karyawan untuk berprestasi melampaui harapan. Dalam hal ini para karyawan merasa percaya, kagum, loyal dan hormat kepada pemimpinnya, sehingga mereka termotivasi lebih dari apa yang diharapkan dari mereka. Bahkan tidak jarang melampaui apa yang mereka perkirakan dapat mereka lakukan. Model kepemimpinan yang berkembang pesat dalam dua dekade terakhir ini didasarkan lebih pada upaya pemimpin untuk mengubah berbagai nilai, keyakinan dan kebutuhan bawahan (Tjiptono, 2005). Kepemimpinan transformasional dapat didefinisikan sebagai kepemimpinan yang mencakup upaya perubahan organisasi. Diyakini bahwa gaya ini akan mengarah pada kinerja superior dalam organisasi yang sedang menghadapi tuntutan pembangunan dan perubahan. Seorang pemimpin dapat mentransformasikan bawahannya melalui empat cara yang disebut Empat I (Bass \& Avolio, 1994), yaitu: (1) idealized influence (charisma), (2) inspirational motivaiton, (3) intelectual simulation, dan (4) individualized consideration.

Kharisma merupakan salah satu dimensi penting dalam kepemimpinan transformasional yang sekaligus menjadi prediktor terkuat atas hasil kepemimpinan (leadership outcomes), seperti usaha esktra para bawahan, komitmen terhadap organisasi, kepuasan terhadap pemimpin, dan penilaian bawahan terhadap ketrampilan kepemimpinan (Bass, 1994). Sebagai elemen penting, kepemimpinan 
kharismatik berperanan sebagai necessary but not sufficient condition bagi kepemimpinan transformasional (Bass, 1994).

Untuk mengukur kapasitas kepemimpinan bagi perguruan tinggi dalam mendukung daya saing pergururan tinggi, diungkapkan oleh Gupta (1983) yaitu: (1) memiliki dua tipe kepemimpinan, yaitu sebagai status leader dan official leader; sebagai status leader dia harus dapat diterima oleh semua anggota kelompok; dan sebagai official leader dia harus bersifat fatherly; (2) memiliki kemampuan dalam memberikan kewenangan dan delegasi kepada staf; (3) Memiliki perhatian yang tinggi kepada staf; (4) dapat mencipatakan atmosfer kepuasan kerja.

Pada tahun-tahun mendatang, perguruan tinggi Indonesia akan menghadapi berbagai tantangan besar yang perlu dan harus direspons dengan strategis. Globalisasi ekonomi dan revolusi teknologi informasi adalah dua kekuatan besar yang sangat mempengaruhi dunia perguruan tinggi Indonesia. Jika perguruan tinggi tidak mampu mengantisipasi tantangan globalisasi dengan memadai, diperkirakan lembaga tersebut tidak mampu mempertahankan eksistensinya. Oleh karena itu perlu bagi perguruan tinggi di Indonesia untuk terus meningkatkan kekuatan daya saingnya agar tetap mampu bertahan. Berdasarkan pandangan-pandangan dan argumentasi yang disampaikan oleh para ahli di atas maka peran pemimpin merupakan kekuatan utama dalam meningkatkan daya saing perguruan tinggi. Konsep yang ingin dikemukakan secara umum dapat dijelaskan pada Gambar 3 berikut ini.

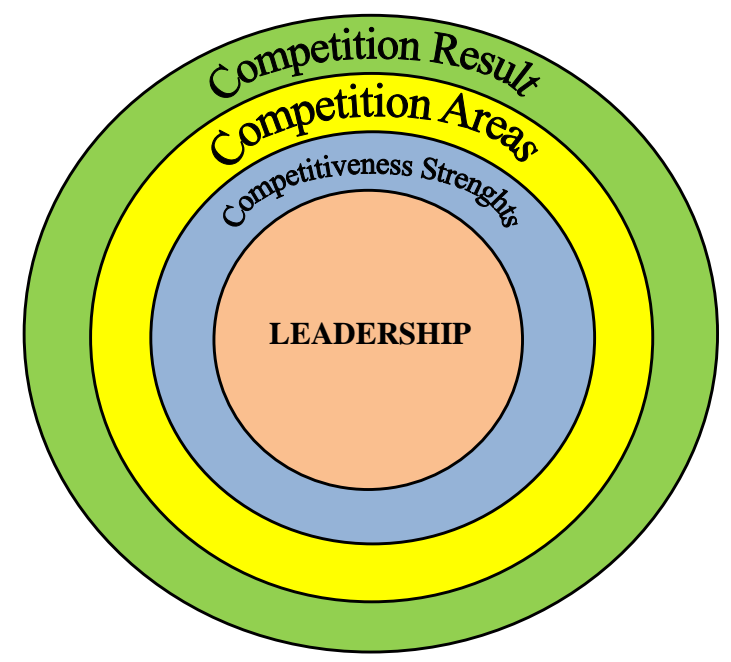

Gambar 3 Leadership sebagai Primary Forces dalam Meningkatkan Daya Saing Perguruan Tinggi

Leadership sebagai primary forces meliputi meliputi aspek: personality integrity; proactive; resourceful; dan managerial strategies. Kepemimpinan ini akan mengoptimalkan Competitiveness Strengths yang terdiri variabel-variabel relevance of curriculum content; teaching learning processes; faculty welfare; quality of faculty members; student advisement; academic administration; financial capabilities; networking; dan quality of graduates. Arena yang dihadapi disebut dengan Competition Areas yang meliputi aspek: customers; product knowledge; consultanty; research grant; retaining and continuing student; dan international student. Hasil akhir dari semua ini akan menghasilkan variabel Competition Result meliputi aspek: adequacy in quality and quantity of student; favorable income; social-cultural respect; dan better image. 


\section{SIMPULAN}

Berdasarkan kajian yang telah dikemukakan pada bagian pembahasan maka dapat disimpulkan bahwa aspek Kepemimpinan (leadership) PTS sebagai driving force untuk menggerakkan Kekuatan Daya Saing (competitiveness strengths) perguruan tinggi dalam rangka memenangkan Area Persaingan (competition areas) sehingga dapat memperoleh Hasil Persaingan (competition result) sesuai yang diharapkan baik dari segi kecukupan kualitas dan kuantitas mahasasiswa, pendapatan yang layak, penghormatan sosial dan budaya terhadap organisasi dan citra yang baik. Beberapa rekomendasi yang dapat disampaikan atas hasil kesimpulan yang telah dikemukakan adalah : (1) dalam upaya menselaraskan Relevance of Curriculum Content yang dapat mengikuti perkembangan dan dinamisasi industri dan pengguna lulusan lainnya, maka Pimpinan perguruan tinggi perlu memiliki kemampuan yang dapat dengan cepat menggerakkan sumber daya dan kapabilitas organisasi untuk mengatasi masalah tersebut; (2) guna mewujudkan quality of faculty members melalui faculty welfare, maka peran pemimpin dalam mengupayakan kesejahteraan dosen dan pegawai perguruan tinggi dapat dilakukan dengan menggali sumber-sumber dana potensial disamping SPP dari mahasiswa seperti : menghasilkan produk-produk ilmu pengetahuan yang dapat dijual, kegiatan konsultasi dan penelitian; (3) dalam rangka menciptakan ketertiban dan kerapihan pengelolaan administrasi kegiatan akademik di perguruan tinggi, kemampuan leader dalam mendorong motivasi, kreativitas, inovasi dan dapat menjadi sumber inspirasi bagi bawahan perlu lebih kongkrit dilakukan dengan menjalankan fungsi-fungsi managerial secara sistematis. Fungsi manajerial ini meliputi perencanaan, pengorganisasian, kepemimpinan dan pengendalian. Dalam hal ini, maka pengembangan perguruan tinggi perlu didasarkan pada formulasi visi, misi dan tujuan yang jelas, sehingga implementasi strategi dan evaluasinya dapat dilakukan dengan lebih baik; (4) unsur resourceful dan managerial strategies yang masih belum optimal menjadi salah satu penyebab, lemahnya para leader dalam membangun networking perguruan tinggi. Pemahaman leader atas sumber daya atau kapabilitas yang dimiliki organisasi menjadi sesuatu yang sangat diperlukan, karena dengan demikian seorang pemimpin dengan potensi managerial strategies yang ada pada dirinya seperti srategic thinking, strategic alliance dan strategic Action (marketing strategic dan public relations) dapat meningkatkan daya saing organisasi.

\section{DAFTAR PUSTAKA}

Alma, B. (2005). Manajemen pemasaran dan pemasaran jasa. Bandung: Alfabeta.

Alma, B. (2005). Pemasaran stratejik jasa pendidikan. Bandung: Alfabeta.

Bass, B., \& Avolio, B. (1994). Improving organizational effectiveness through transformational leadership. London: Sage Publications.

Bennis, W., \& Nanus, B. (1995). Leaders, the strategies for taking charge. (V. Purba, Terj.). Jakarta: Erlangga.

Brodjonegoro, S. S. (2004). Beberapa pemikiran dalam rangka peningkatan mutu dan daya saing perguruan tinggi. Makalah pada Teaching Improvement Workshop, ADB Loan, Universitas Riau.

Cyert, R. M. (1993). Universities, competitiveness and TQM: a plan of action for the year 2000. Public Administration Quarterly (Online), Vol. 17 No.1,pp.10-18.

Cravens, D. W. (1996). Pemasaran strategis (4th ed.). Jakarta: Erlangga. 
Damanhuri, D. S. (2003). SDM Indonesia dalam persaingan global. Suara Pembaruan (13 Juni 2003).

Departemen Pendidikan Nasional. (2003). Undang-Undang Republik Indonesia Nomor 20 Tahun 2003 Tentang Sistem Pendidikan Nasional. Jakarta: Depdiknas.

Duderstadt, J. J. (2003) A university for the 21st century. USA: The University of Michigan Press.

Djojohadikusumo, S. (1993). Ilmu pengetahuan, teknologi dan pembangunan. Pidato Ilmiah di Institut Teknologi Adityawarman ,4 September 1993, Bandung.

Drucker, P. F. (1990) Managing the nonprofit organization-principles and practices. New York: Harper Collins Publisher.

Elmuti, et al (2005). An overview of strategic alliances between universities and corporations. Journal of Workplace Learning, 17, 1/2, ABI/INFORM Global.

Grant, R. M. (1991). The resource base theory of competitive advantage. Management Review; 33 (3); pg.114-135.

Gupta, L. D. (1983 ). Educational administration at college level. New Delhi: Mohan Primlani.

Ham, L., \& Hayduk, S. (2003). Gaining competitive advantages in higher education: analyzing the gap between expectations and perceptions of service quality. International Journal of Value-Based Management, Vol. 16, No. 3, halaman : 223-238.

Hanafi. (1997). Manajemen. Yogyakarta: YKPN.

Hitt, M. A., et al. (2001). Strategic management-competitiveness and globalization (4th ed.). USA: Thomson Learnin.

Indrajit, E. R., \& Djokopranoto, R. (2006). Manajemen perguruan tinggi modern. Yogyakarta: Andi Offset.

Jedamus, P., Peterson, M. W., \& Associates. (1980). Improving academic management. USA: John Wiley and Sons.

Lindelof, P., \& Lofsten, L. (2004). Proximity as a resource base for competitive advantage: universityindustry links for technology transfer. Journal of Technology Transfer (Online). Aug 2004; 29; 3-4.

Miller, R. I. (1980). Appraising Institutional Performance. Improving Academic Management, USA: John Wiley and Sons.

Moedjadi. (2005). Pengaruh persaingan dan organisasi belajar (learning organization) terhadap proses transformasi kompetensi intelektual individu menjadi modal intelektual organisasi. Disertasi Doktor pada PPS-UPI Bandung: tidak diterbitkan.

Nasution, M. (2004). Evolusi pembaharuan atau evolusi pemikiran mengenai organisasi, visi dan misi suatu perguruan tinggi. Makalah pada Ceramah di IKOPIN, Bandung.

Porter, M. E. (1993).Competitive advantage. USA: Collier Macmillan Publisers.

Rangkuti, F. (1998).Analisis SWOT teknik membedah kasus bisnis. Jakarta: Gramedia. 
Sallis, E. (1993). Total quality management in education. London: Kogan Page Limited.

Schermerhorn, Jr., J. R. (1999). Management (5th ed.). (P. Putranto et.al., Terj.). Yogyakarta: Manajemen Studi.

Soegoto, E. S. (2008). Menciptakan strategi keunggulan bersaing perguruan tinggi. Yogyakarta: Graha Ilmu.

Tjiptono, F. (2005). Pemasaran Jasa (1st ed.). Jawa Timur: Bayu Media.

Walker, G. (2007). Modern competitive strategy (2nd ed.). New York: The Mc.Graw Hill Companies.

Wheelen, T. L., \& Hunger, J. D. (1995). Strategic management and business policy (5th ed.). United States of America: Addison-Wesley Publishing.

Winardi. (2003). Kreativitas dan teknik-teknik pemikiran kreatif dalam bidang manajemen. Bandung: Citra Aditya.

Yukl, G. A. (1998). Leadership in organizations (4th ed.). Englewood Cliffs, N.J.: Prentice-Hall.

\section{RIWAYAT PENULIS}

Engkos Achmad Kuncoro, lahir di kota Jepara Jawa Tengah pada tangal 11 Juni 1967. Penulis menamatkan pendidikan S1 di Institut Manajemen Koperasi Indonesia (Ujian Negara Tertulis dan Lisan di Universitas Padjadjaran Bandung) pada tahun 1991, S2 Institut Pertanian Bogor (IPB), Program Magister Manajemen, pada tahun 1993 dan S3 di Universitas Pendidikan Indonesia (UPI) Bandung, dalam bidang Administrasi Pendidikan, pada tahun 2008. Saat ini berkerja sebagai Dekan Fakultas Ekonomi dan Bisnis di Universitas Bina Nusantara. Penulis tercatat sebagai anggota Ikatan Sarjana Ekonomi Indonesia (ISEI) dan Anggota Dewan Pakar Dewan Koperasi Indonesia (DEKOPIN). 